\title{
Mesowear as a means of determining diets in African antelopes
}

\author{
Julien Louys $^{\mathrm{a}, *}$, Carlo Meloro ${ }^{\mathrm{b}}$, Sarah Elton ${ }^{\mathrm{b}}$, Peter Ditchfield ${ }^{\mathrm{c}}$, Laura C. Bishop ${ }^{\mathrm{a}}$

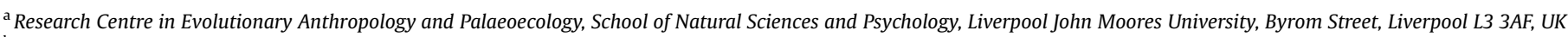 \\ ${ }^{\mathrm{b}}$ Functional Morphology and Evolution Unit, Hull York Medical School, University of Hull, Cottingham Road, Hull HU6 7RX, UK \\ ${ }^{\mathrm{c}}$ Research Laboratory for Archaeology and the History of Art, School of Archaeology, University of Oxford, Dyson Perrins Building, South Parks Road, Oxford OX1 3QY, UK
}

\section{A R T I C L E I N F O}

\section{Article history:}

Received 2 December 2010

Received in revised form

14 February 2011

Accepted 15 February 2011

\section{Keywords:}

Palaeoecology

Palaeoenvironment

Tooth wear

Trophic guild

\section{Introduction}

The diets of African antelopes (Mammalia: Bovidae) are very broad and range from strict grazing to frugivory to mixed feeding (Gagnon and Chew, 2000). Antelopes have been amongst the most commonly used mammals for environmental reconstruction at archaeological and palaeontological sites in Africa because of their diversity and abundance both today and in the fossil record (e.g. Kappelman et al., 1997; Plummer and Bishop, 1994; Kovarovic et al., 2002; Plummer et al., 2008; Stynder, 2009; Blondel et al., 2010), as well as the wealth of modern ecological research which has been conducted on them. Antelope gnathic elements are common finds at African sites and have significant potential for palaeodietary reconstructions which by inference provide information about ancient habitats.

Modern antelopes teeth should demonstrate close to the full range of masticatory wear because as a group they encompass such broad spectrum of dietary niches. An animal's dentition experiences wear during mastication through contact with food, as well as through the grinding of teeth against other teeth (Hillson, 2005). Two types of wear are generally identified: attritional wear refers to

\footnotetext{
* Corresponding author.

E-mail address: j.louys@ljmu.ac.uk (J. Louys).
}

the formation of wear facets through tooth-on-tooth contact, while abrasive wear occurs through tooth-on-food contact (Hillson, 2005). The cumulative dental wear an animal experiences during its lifetime results in particular tooth morphologies, the study of which is now commonly referred to as mesowear analysis. The potential of this type of wear as an indicator of diet was first set out in a landmark study by Fortelius and Solounias (2000), and since then the application of this method in palaeontological studies has been prolific (e.g. Blondel et al., 2010; Stynder, 2009, 2011; Joomun et al., 2008; Croft and Weinstein, 2008; Kaiser et al., 2003; Rivals et al., 2007a, 2008; Rivals and Athanassiou, 2008). Furthermore, the original methodology detailed by Fortelius and Solounias (2000) has both been amended and expanded (e.g. FranzOdendaal and Kaiser, 2003; Kaiser et al., 2000, 2003; Kaiser and Solounias, 2003; Kaiser and Fortelius, 2003; Schulz et al., 2007; Mihlbachler and Solounias, 2006; Rivals et al., 2007a, b; 2009). However, to the best of our knowledge, the original dataset based on the second upper molar provided by Fortelius and Solounias (2000) remains the only comparative dataset available for researchers hoping to use and improve upon this method.

\section{Materials and methods}

We investigated the distribution of mesowear variables amongst 33 modern African antelope species (Table 1). Traditional 
Table 1

Antelope species examined in this study and their dietary categories according to different authors; only those for which a category is listed in the first column were part of the 'typical' herbivore set proposed by Fortelius and Solounias (2000).

\begin{tabular}{|c|c|c|c|}
\hline \multirow[b]{2}{*}{ Species } & \multicolumn{3}{|l|}{ Diet category } \\
\hline & $\begin{array}{l}\text { Fortelius and } \\
\text { Solounias (2000) } \\
\text { 'conservative' }\end{array}$ & $\begin{array}{l}\text { Gagnon and } \\
\text { Chew (2000) }\end{array}$ & This study \\
\hline Alcelaphus buselaphus & Grazer & Variable grazer & Grazer \\
\hline Alcelaphus lichtensteini & Grazer & Obligate grazer & Grazer \\
\hline Antidorcas marsupialis & Mixed & $\begin{array}{l}\text { Browser-Grazer } \\
\text { intermediate }\end{array}$ & Mixed \\
\hline Cephalophus dorsalis & Browser & Frugivore & Frugivore \\
\hline Cephalophus leucogaster & & Frugivore & Frugivore \\
\hline Cephalophus maxwelli & & Frugivore & Frugivore \\
\hline Cephalophus niger & Browser & Frugivore & Frugivore \\
\hline Cephalophus nigrifrons & Browser & Frugivore & Frugivore \\
\hline Cephalophus silvicultor & Browser & Frugivore & Frugivore \\
\hline Cephalophus weynsi & & Frugivore & Frugivore \\
\hline Gazella dorcas & & Generalist & Mixed \\
\hline Gazella granti & Mixed & Variable grazer & Grazer \\
\hline Gazella leptoceros & & $\begin{array}{l}\text { Browser-Grazer } \\
\text { intermediate }\end{array}$ & Mixed \\
\hline Gazella rufifrons & & $\begin{array}{l}\text { Browser-Grazer } \\
\text { intermediate }\end{array}$ & Mixed \\
\hline Gazella soemmerringi & & $\begin{array}{l}\text { Browser-Grazer } \\
\text { intermediate }\end{array}$ & Mixed \\
\hline Hippotragus equinus & Grazer & Variable grazer & Grazer \\
\hline Kobus ellipsiprymnus & Grazer & Variable grazer & Grazer \\
\hline Kobus kob & & Obligate grazer & Grazer \\
\hline Kobus leche & & Obligate grazer & Grazer \\
\hline Litocranius walleri & Browser & Browser & Browser \\
\hline Neotragus batesi & & Browser & Browser \\
\hline Ourebia ourebi & Mixed & Variable grazer & Grazer \\
\hline Philantomba monticola & & Frugivore & Frugivore \\
\hline Redunca arundinum & & Obligate grazer & Grazer \\
\hline Redunca redunca & Grazer & Obligate grazer & Grazer \\
\hline Sylvicapra grimmia & & Browser & Browser \\
\hline Syncerus caffer & Mixed & Variable grazer & Grazer \\
\hline Taurotragus oryx & Mixed & $\begin{array}{l}\text { Browser-Grazer } \\
\text { intermediate }\end{array}$ & Mixed \\
\hline Tragelaphus angasi & Mixed & Generalist & Mixed \\
\hline Tragelaphus eurycerus & Browser & Browser & Browser \\
\hline Tragelaphus scriptus & Mixed & Browser & Browser \\
\hline Tragelaphus spekii & & Variable grazer & Grazer \\
\hline Tragelaphus strepsiceros & Browser & Generalist & Mixed \\
\hline
\end{tabular}

mesowear methods only examine the M2, but we also investigated the distribution of mesowear variables amongst all upper and lower molars in order to determine quantitatively which tooth best discriminates between different trophic guilds. This analysis would also potentially allow extension of the mesowear method to fossil mandibles, or to maxillary fragments that have damaged or missing M2s.

We examined only wild caught antelopes housed in The Natural History Museum (London, UK), the Musée d'Histoire Naturelle de Paris (Paris, France) and the Koninklijk Museum voor MiddenAfrika (Tervuren, Belgium). We included all species with five or more specimens in our analysis to facilitate comparisons between our antelope database and the values recorded for modern species by Fortelius and Solounias (2000). Nineteen of the 33 antelope species we examined were also scored by Fortelius and Solounias (2000: Table 1). One of us (JL) took mesowear scores from all specimens to eliminate the possibility of inter-observational error. Only mature individuals where the M3s were in wear were included in the sample: old and juvenile individuals were excluded from this study.

We examined results using three different schemata for categorising diet (Table 1). First, species were categorised into the three trophic categories normally used in mesowear studies (namely grazer, browser and mixed feeder, see Fortelius and Solounias
(2000) for details of how these categories were determined). Second, species were assigned to one of six more detailed dietary categories defined by Gagnon and Chew (2000). Finally, the six categories system was further reduced into four: grazers (variable and obligate grazers), mixed feeders (browser-grazer intermediates and generalists), browsers ( $>70 \%$ dicots) and frugivores $(>70 \%$ fruits). These categories are similar but not identical to the definitions used by Fortelius and Solounias (2000) with the addition of a frugivore category. We feel that this four category scheme allows for the maximum level of accurate discrimination we could expect in the fossil taxa.

Traditional mesowear analyses examine two qualitative indices developed for the M2 (Fortelius and Solounias, 2000). The first assesses the relative sharpness of the sharpest buccal cusp, scoring it as sharp, round or blunt. We follow this method for the upper molars, but score the sharpest lingual cusp for the lower molars. This is because the lingual cusps of lower molars are functionally analogous with the buccal cusps of the upper molars in terms of abrasive wear. The second index examines the relative height of the valley between the two cusps examined for sharpness above. High or low valleys can be classified by dividing the distance from the bottom of the valley to the level of the cusps by the length of the molar (Fig. 1). This variable can be scored visually, but to facilitate metric analyses we took measurements using digital callipers and calculated the distance quantitatively. We follow Fortelius and Solounias (2000) in categorising height indices of less than 0.1 as low, with the exception of the m3. Because the $\mathrm{m} 3$ in antelopes has three lobes and is thus longer, we calculated that an index of 0.08 is approximately equivalent to that of 0.1 for the other molars. We calculated the percentage of individuals within each species sample displaying sharp (\%Sharp), round (\%Round), blunt (\%Blunt) and high (\%High) cusps for each of the molar positions (Tables 2 and 3 ).

\subsection{Statistical analyses}

We calculated the relative proportions of species falling in the \% High, \% Sharp, \% Round and \% Blunt categories to compare our mesowear scores with those of Fortelius and Solounias (2000). We ran a Mann-Whitney $U$ test between our values and those of Fortelius and Solounias (2000) for the species we scored in common $(n=19)$.

Many mesowear studies (e.g. Croft and Weinstein, 2008; Stynder, 2009, 2011) determine fossil species diets on the basis of a cluster analysis with a 'typical' set of 27 herbivores, as originally suggested by Fortelius and Solounias (2000). These were originally selected as their clustering pattern on the basis of mesowear score was relatively "free of anomalies" (Fortelius and Solounias, 2000; p.

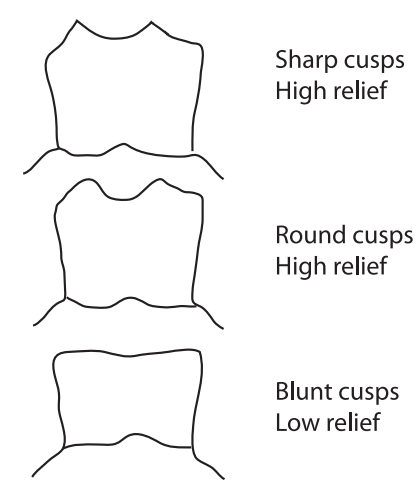

Fig. 1. Stylised representation of mesowear variables used in this study. 
Table 2

Mesowear scores for upper molars of antelope species examined in this study.

\begin{tabular}{|c|c|c|c|c|c|c|c|c|c|c|c|c|c|c|c|}
\hline \multirow[b]{2}{*}{ Species } & \multicolumn{5}{|c|}{ M1 } & \multicolumn{5}{|c|}{ M2 } & \multicolumn{5}{|l|}{ M3 } \\
\hline & $\mathrm{n}$ & \% Sharp & \% Round & $\%$ Blunt & $\%$ High & $\mathrm{n}$ & \% Sharp & $\%$ Round & $\%$ Blunt & $\%$ High & $\mathrm{n}$ & \% Sharp & \% Round & $\%$ Blunt & \% High \\
\hline Alcelaphus buselaphus & 17 & 0.0 & 94.1 & 5.9 & 11.8 & 17 & 40.0 & 60.0 & 0.0 & 100.0 & 17 & 5.9 & 94.1 & 0.0 & 82.4 \\
\hline Alcelaphus lichtensteini & 6 & 0.0 & 83.3 & 16.7 & 0.0 & 7 & 100.0 & 0.0 & 0.0 & 91.7 & 7 & 0.0 & 100.0 & 0.0 & 28.6 \\
\hline Antidorcas marsupialis & 16 & 12.5 & 81.3 & 6.3 & 68.8 & 16 & 33.3 & 66.7 & 0.0 & 85.2 & 15 & 26.7 & 73.3 & 0.0 & 80.0 \\
\hline Cephalophus dorsalis & 22 & 4.5 & 59.1 & 36.4 & 13.6 & 22 & 7.7 & 92.3 & 0.0 & 92.3 & 22 & 50.0 & 50.0 & 0.0 & 72.7 \\
\hline Cephalophus leucogaster & 11 & 0.0 & 81.8 & 18.2 & 9.1 & 11 & 29.2 & 70.8 & 0.0 & 100.0 & 11 & 90.9 & 9.1 & 0.0 & 81.8 \\
\hline Cephalophus maxwelli & 12 & 16.7 & 75.0 & 8.3 & 8.3 & 12 & 6.3 & 93.8 & 0.0 & 81.3 & 12 & 66.7 & 33.3 & 0.0 & 91.7 \\
\hline Cephalophus niger & 6 & 0.0 & 100.0 & 0.0 & 0.0 & 6 & 80.0 & 20.0 & 0.0 & 100.0 & 6 & 50.0 & 50.0 & 0.0 & 100.0 \\
\hline Cephalophus nigrifrons & 27 & 22.2 & 63.0 & 14.8 & 25.9 & 27 & 0.0 & 100.0 & 0.0 & 77.8 & 27 & 70.4 & 29.6 & 0.0 & 88.9 \\
\hline Cephalophus silvicultor & 24 & 12.5 & 54.2 & 33.3 & 29.2 & 24 & 20.0 & 80.0 & 0.0 & 70.0 & 23 & 39.1 & 56.5 & 4.3 & 82.6 \\
\hline Cephalophus weynsi & 27 & 0.0 & 70.4 & 29.6 & 14.8 & 27 & 14.3 & 85.7 & 0.0 & 100.0 & 26 & 61.5 & 38.5 & 0.0 & 73.1 \\
\hline Gazella dorcas & 19 & 0.0 & 89.5 & 10.5 & 63.2 & 20 & 27.3 & 59.1 & 13.6 & 50.0 & 19 & 47.4 & 52.6 & 0.0 & 78.9 \\
\hline Gazella granti & 9 & 0.0 & 100.0 & 0.0 & 88.9 & 12 & 54.5 & 45.5 & 0.0 & 27.3 & 11 & 63.6 & 36.4 & 0.0 & 81.8 \\
\hline Gazella leptoceros & 5 & 20.0 & 60.0 & 20.0 & 60.0 & 5 & 41.7 & 58.3 & 0.0 & 50.0 & 0 & & & & \\
\hline Gazella rufifrons & 10 & 10.0 & 70.0 & 20.0 & 30.0 & 9 & 50.0 & 50.0 & 0.0 & 83.3 & 9 & 55.6 & 44.4 & 0.0 & 88.9 \\
\hline Gazella soemmerringi & 10 & 10.0 & 60.0 & 30.0 & 50.0 & 10 & 40.7 & 59.3 & 0.0 & 74.1 & 11 & 45.5 & 54.5 & 0.0 & 72.7 \\
\hline Hippotragus equinus & 23 & 0.0 & 91.3 & 8.7 & 65.2 & 22 & 4.2 & 87.5 & 8.3 & 70.8 & 21 & 4.8 & 95.2 & 0.0 & 100.0 \\
\hline Kobus ellipsiprymnus & 25 & 0.0 & 88.0 & 12.0 & 68.0 & 26 & 22.2 & 74.1 & 3.7 & 44.4 & 25 & 4.0 & 96.0 & 0.0 & 100.0 \\
\hline Kobus kob & 11 & 0.0 & 100.0 & 0.0 & 36.4 & 11 & 22.2 & 66.7 & 11.1 & 16.7 & 12 & 0.0 & 100.0 & 0.0 & 75.0 \\
\hline Kobus leche & 0 & & & & & 5 & 20.0 & 80.0 & 0.0 & 75.0 & 5 & 0.0 & 100.0 & 0.0 & 80.0 \\
\hline Litocranius walleri & 5 & 20.0 & 80.0 & 0.0 & 100.0 & 5 & 20.0 & 80.0 & 0.0 & 100.0 & 0 & & & & \\
\hline Neotragus batesi & 13 & 69.2 & 23.1 & 7.7 & 61.5 & 12 & 22.2 & 77.8 & 0.0 & 88.9 & 13 & 92.3 & 7.7 & 0.0 & 100.0 \\
\hline Ourebia ourebi & 5 & 0.0 & 100.0 & 0.0 & 80.0 & 6 & 0.0 & 100.0 & 0.0 & 14.3 & 6 & 16.7 & 83.3 & 0.0 & 83.3 \\
\hline Philantomba monticola & 18 & 27.8 & 61.1 & 11.1 & 27.8 & 18 & 0.0 & 100.0 & 0.0 & 81.8 & 18 & 72.2 & 27.8 & 0.0 & 55.6 \\
\hline Redunca arundinum & 24 & 0.0 & 87.5 & 12.5 & 50.0 & 24 & 0.0 & 100.0 & 0.0 & 80.0 & 24 & 20.8 & 79.2 & 0.0 & 100.0 \\
\hline Redunca redunca & 20 & 0.0 & 95.0 & 5.0 & 60.0 & 25 & 4.3 & 95.8 & 0.0 & 83.3 & 25 & 0.0 & 100.0 & 0.0 & 100.0 \\
\hline Sylvicapra grimmia & 27 & 22.2 & 59.3 & 18.5 & 33.3 & 27 & 0.0 & 100.0 & 0.0 & 84.0 & 27 & 66.7 & 33.3 & 0.0 & 92.6 \\
\hline Syncerus caffer & 6 & 0.0 & 100.0 & 0.0 & 16.7 & 6 & 0.0 & 100.0 & 0.0 & 29.4 & 6 & 0.0 & 100.0 & 0.0 & 50.0 \\
\hline Taurotragus oryx & 9 & 0.0 & 100.0 & 0.0 & 55.6 & 7 & 8.3 & 91.7 & 0.0 & 66.7 & 9 & 33.3 & 66.7 & 0.0 & 100.0 \\
\hline Tragelaphus angasi & 0 & & & & & 5 & 0.0 & 100.0 & 0.0 & 95.5 & 0 & & & & \\
\hline Tragelaphus eurycerus & 16 & 18.8 & 81.3 & 0.0 & 62.5 & 13 & 3.8 & 96.2 & 0.0 & 100.0 & 17 & 29.4 & 70.6 & 0.0 & 100.0 \\
\hline Tragelaphus scriptus & 23 & 13.0 & 87.0 & 0.0 & 95.7 & 24 & 16.7 & 83.3 & 0.0 & 83.3 & 24 & 62.5 & 37.5 & 0.0 & 100.0 \\
\hline Tragelaphus spekii & 20 & 25.0 & 70.0 & 5.0 & 70.0 & 20 & 0.0 & 100.0 & 0.0 & 50.0 & 21 & 47.6 & 52.4 & 0.0 & 100.0 \\
\hline Tragelaphus strepsiceros & 10 & 10.0 & 90.0 & 0.0 & 50.0 & 9 & 45.0 & 55.0 & 0.0 & 90.0 & 10 & 60.0 & 40.0 & 0.0 & 100.0 \\
\hline
\end{tabular}

3301). We ran these analyses using our mesowear values for the species shared in common with Fortelius and Solounias (2000). Two cluster analyses were run in order to examine the effect of our mesowear scores on the topology of the dendrogram: the first with only the 27 'typical' species and the second with the 27 'typical' species as well as the remainder of our antelope species.

We performed a discriminant function analysis (DFA), again using the 27 'typical' herbivores (with our antelope values), in

Table 3

Mesowear scores for lower molars of antelope species examined in this study.

\begin{tabular}{|c|c|c|c|c|c|c|c|c|c|c|c|c|c|c|c|}
\hline \multirow[b]{2}{*}{ Species } & \multicolumn{5}{|c|}{$\mathrm{m} 1$} & \multicolumn{5}{|l|}{$\mathrm{m} 2$} & \multicolumn{5}{|l|}{$\mathrm{m} 3$} \\
\hline & $\mathrm{n}$ & \% Sharp & \% Round & \% Blunt & \% High & $\mathrm{n}$ & \% Sharp & \% Round & $\%$ Blunt & \% High & $\mathrm{n}$ & \% Sharp & \% Round & \% Blunt & $\%$ High \\
\hline Alcelaphus buselaphus & 8 & 0.0 & 100.0 & 0.0 & 87.5 & 8 & 0.0 & 100.0 & 0.0 & 87.5 & 7 & 0.0 & 100.0 & 0.0 & 100.0 \\
\hline Alcelaphus lichtensteini & 5 & 0.0 & 100.0 & 0.0 & 0.0 & 5 & 0.0 & 100.0 & 0.0 & 60.0 & 5 & 0.0 & 100.0 & 0.0 & 80.0 \\
\hline Antidorcas marsupialis & 10 & 0.0 & 90.0 & 10.0 & 40.0 & 9 & 0.0 & 100.0 & 0.0 & 77.8 & 7 & 14.3 & 85.7 & 0.0 & 14.3 \\
\hline Cephalophus dorsalis & 20 & 0.0 & 30.0 & 70.0 & 10.0 & 20 & 15.0 & 70.0 & 15.0 & 50.0 & 20 & 30.0 & 70.0 & 0.0 & 55.0 \\
\hline Cephalophus leucogaster & 11 & 0.0 & 27.3 & 72.7 & 9.1 & 11 & 0.0 & 81.8 & 18.2 & 45.5 & 10 & 40.0 & 60.0 & 0.0 & 40.0 \\
\hline Cephalophus maxwelli & 10 & 0.0 & 40.0 & 60.0 & 10.0 & 10 & 40.0 & 60.0 & 0.0 & 80.0 & 9 & 77.8 & 22.2 & 0.0 & 88.9 \\
\hline Cephalophus niger & 5 & 0.0 & 20.0 & 80.0 & 20.0 & 5 & 20.0 & 80.0 & 0.0 & 100.0 & 5 & 20.0 & 80.0 & 0.0 & 100.0 \\
\hline Cephalophus nigrifrons & 24 & 0.0 & 58.3 & 41.7 & 25.0 & 24 & 37.5 & 45.8 & 16.7 & 66.7 & 23 & 65.2 & 34.8 & 0.0 & 78.3 \\
\hline Cephalophus silvicultor & 23 & 0.0 & 34.8 & 65.2 & 8.7 & 24 & 4.2 & 66.7 & 29.2 & 54.2 & 21 & 28.6 & 51.9 & 4.8 & 61.9 \\
\hline Cephalophus weynsi & 25 & 0.0 & 48.0 & 52.0 & 8.0 & 25 & 20.0 & 68.0 & 12.0 & 56.0 & 24 & 41.7 & 54.2 & 4.2 & 70.8 \\
\hline Gazella dorcas & 10 & 20.0 & 70.0 & 10.0 & 80.0 & 9 & 55.6 & 44.4 & 0.0 & 100.0 & 9 & 22.2 & 77.8 & 0.0 & 100.0 \\
\hline Gazella granti & 6 & 16.7 & 66.7 & 16.7 & 50.0 & 6 & 33.3 & 66.7 & 0.0 & 83.3 & 0 & & & & \\
\hline Gazella rufifrons & 5 & 0.0 & 100.0 & 0.0 & 40.0 & 5 & 20.0 & 80.0 & 0.0 & 100.0 & 5 & 20.0 & 80.0 & 0.0 & 100.0 \\
\hline Gazella soemmerringi & 6 & 0.0 & 66.7 & 33.3 & 66.7 & 6 & 33.3 & 66.7 & 0.0 & 83.3 & 6 & 33.3 & 66.7 & 0.0 & 100.0 \\
\hline Hippotragus equinus & 18 & 0.0 & 88.9 & 11.1 & 83.3 & 20 & 0.0 & 100.0 & 0.0 & 100.0 & 17 & 11.8 & 88.2 & 0.0 & 100.0 \\
\hline Kobus ellipsiprymnus & 22 & 0.0 & 100.0 & 0.0 & 86.4 & 22 & 0.0 & 100.0 & 0.0 & 100.0 & 19 & 5.3 & 94.7 & 0.0 & 100.0 \\
\hline Kobus kob & 6 & 0.0 & 83.3 & 16.7 & 83.3 & 5 & 0.0 & 100.0 & 0.0 & 100.0 & 7 & 28.6 & 71.4 & 0.0 & 100.0 \\
\hline Neotragus batesi & 13 & 53.8 & 46.2 & 0.0 & 92.3 & 13 & 76.9 & 23.1 & 0.0 & 100.0 & 12 & 83.3 & 16.7 & 0.0 & 83.3 \\
\hline Ourebia ourebi & 6 & 0.0 & 100.0 & 0.0 & 33.3 & 6 & 0.0 & 100.0 & 0.0 & 100.0 & 6 & 50.0 & 50.0 & 0.0 & 100.0 \\
\hline Philantomba monticola & 18 & 11.1 & 83.3 & 5.6 & 50.0 & 18 & 22.2 & 66.7 & 11.1 & 61.1 & 17 & 58.8 & 35.3 & 5.9 & 82.4 \\
\hline Redunca arundinum & 21 & 0.0 & 95.2 & 4.8 & 76.2 & 24 & 4.2 & 95.8 & 0.0 & 100.0 & 22 & 22.7 & 77.3 & 0.0 & 100.0 \\
\hline Redunca redunca & 21 & 0.0 & 90.5 & 9.5 & 76.2 & 20 & 5.0 & 95.0 & 0.0 & 95.0 & 16 & 12.5 & 87.5 & 0.0 & 100.0 \\
\hline Sylvicapra grimmia & 23 & 4.3 & 60.9 & 34.8 & 17.4 & 23 & 34.8 & 65.2 & 0.0 & 73.9 & 23 & 73.9 & 26.1 & 0.0 & 91.3 \\
\hline Tragelaphus eurycerus & 9 & 0.0 & 88.9 & 11.1 & 88.9 & 10 & 20.0 & 80.0 & 0.0 & 100.0 & 10 & 60.0 & 40.0 & 0.0 & 100.0 \\
\hline Tragelaphus scriptus & 23 & 8.7 & 91.3 & 0.0 & 95.7 & 24 & 45.8 & 54.2 & 0.0 & 100.0 & 24 & 45.8 & 54.2 & 0.0 & 100.0 \\
\hline Tragelaphus spekii & 15 & 20.0 & 73.3 & 6.7 & 80.0 & 15 & 40.0 & 60.0 & 0.0 & 100.0 & 13 & 53.8 & 46.2 & 0.0 & 100.0 \\
\hline Tragelaphus strepsiceros & 7 & 0.0 & 100.0 & 0.0 & 85.7 & 7 & 14.3 & 85.7 & 0.0 & 100.0 & 5 & 40.0 & 60.0 & 0.0 & 100.0 \\
\hline
\end{tabular}


Table 4

Univariate mesowear scores for each of the antelope species examined in this study, calculated following Rivals et al., (2009).

\begin{tabular}{|c|c|c|c|c|c|c|}
\hline Species & M1 & M2 & M3 & $\mathrm{m} 1$ & $\mathrm{~m} 2$ & m3 \\
\hline Alcelaphus buselaphus & 1.875 & 1.705882 & 1.117647 & 1.125 & 1.125 & 1 \\
\hline Alcelaphus lichtensteini & 2.285714 & 1.857143 & 1.714286 & 2 & 1.4 & 1.2 \\
\hline Antidorcas marsupialis & 1.25 & 1.125 & 0.933333 & 1.7 & 1.222222 & 1.928571 \\
\hline Cephalophus dorsalis & 2.25 & 1.568182 & 0.909091 & 2.6 & 1.65 & 1.15 \\
\hline Cephalophus leucogaster & 2.090909 & 1.590909 & 0.545455 & 2.636364 & 1.727273 & 1.5 \\
\hline Cephalophus maxwelli & 2.083333 & 1.333333 & 0.416667 & 2.5 & 0.95 & 0.333333 \\
\hline Cephalophus niger & 2 & 0.666667 & 0.5 & 2.6 & 0.8 & 0.8 \\
\hline Cephalophus nigrifrons & 1.777778 & 0.851852 & 0.462963 & 2.166667 & 1.375 & 0.695652 \\
\hline Cephalophus silvicultor & 1.916667 & 1.333333 & 0.891304 & 2.565217 & 1.708333 & 1.190476 \\
\hline Cephalophus weynsi & 2.148148 & 1.37037 & 0.653846 & 2.44 & 1.36 & 1.020833 \\
\hline Gazella dorcas & 1.473684 & 1.05 & 0.815789 & 1.1 & 0.444444 & 0.777778 \\
\hline Gazella granti & 1.111111 & 1.25 & 0.818182 & 1.5 & 0.833333 & \\
\hline Gazella leptoceros & 1.4 & 0.2 & & & & \\
\hline Gazella rufifrons & 1.95 & 1.222222 & 0.722222 & 1.6 & 0.8 & 0.8 \\
\hline Gazella soemmerringi & 1.7 & 1.25 & 0.954545 & 1.666667 & 0.833333 & 0.666667 \\
\hline Hippotragus equinus & 1.434783 & 1.045455 & 0.952381 & 1.277778 & 1 & 0.882353 \\
\hline Kobus ellipsiprymnus & 1.44 & 0.961538 & 0.96 & 1.136364 & 1 & 0.947368 \\
\hline Kobus kob & 1.636364 & 1.181818 & 1.25 & 1.333333 & 1 & 0.714286 \\
\hline Kobus leche & & 1.2 & 1.2 & & & \\
\hline Litocranius walleri & 0.8 & 0.6 & & & & \\
\hline Neotragus batesi & 1.115385 & 0.208333 & 0.076923 & 0.538462 & 0.230769 & 0.458333 \\
\hline Ourebia ourebi & 1.2 & 1 & 1.25 & 1.666667 & 1 & 0.5 \\
\hline Philantomba monticola & 1.805556 & 2.055556 & 1.055556 & 1.444444 & 1.361111 & 0.794118 \\
\hline Redunca arundinum & 1.625 & 1.125 & 0.791667 & 1.285714 & 0.958333 & 0.772727 \\
\hline Redunca redunca & 1.45 & 1.16 & 1 & 1.333333 & 1 & 0.875 \\
\hline Sylvicapra grimmia & 1.740741 & 0.814815 & 0.462963 & 2.130435 & 0.978261 & 0.478261 \\
\hline Syncerus caffer & 1.833333 & 1.5 & 1.5 & & & \\
\hline Taurotragus oryx & 1.444444 & 0.857143 & 0.666667 & & & \\
\hline Tragelaphus angasi & & 0.8 & & & & \\
\hline Tragelaphus eurycerus & 1.1875 & 1 & 0.705882 & 1.222222 & 0.8 & 0.4 \\
\hline Tragelaphus scriptus & 0.913043 & 0.708333 & 0.375 & 0.956522 & 0.541667 & 0.541667 \\
\hline Tragelaphus spekii & 1.175 & 0.65 & 0.52381 & 1.066667 & 0.6 & 0.461538 \\
\hline Tragelaphus strepsiceros & 1.4 & 0.888889 & 0.4 & 1.142857 & 0.857143 & 0.6 \\
\hline
\end{tabular}

order to examine the discriminating power of this dataset. In this analysis, we used Fortelius and Solounias's diet classification scheme (2000), and entered all the variables together. It has been suggested that mesowear variables are not independent (Mihlbachler and Solounias, 2006), an assumption of DFAs. Although this has not yet been shown in a quantitative fashion, in order to avoid the possibility of non-independence, we first subjected the raw percentage values of \% High, \% Sharp, \% Round and \% Blunt to a principal components analysis (PCA). This type of analysis rearranges the variables such that the each eigenvector, corresponding to each principal component (PC), is orthogonal to the other.

\subsection{Intratrophic comparisons}

We used $t$-tests, box plots and ANOVA of univariate mesowear scores to make intratrophic comparisons. Following Rivals et al. (2009), we assign the following scores to each mesowear stage: sharp and high (0); sharp and low (2.5); round and high (1); round and low (2); and blunt and low (3). The mesowear scores for each specimen in each species were summed and the average calculated (Table 4). Because of differences in the preservation of molars across a toothrow, different numbers of specimens were scored for each tooth position (Tables 2 and 3).

\subsection{Intertrophic comparisons}

In order to assess the discriminating power of the mesowear at the different tooth positions, we ran each of the mesowear percentages for each of the molars through a PCA. The principal component scores were subsequently run through a DFA (as described in Section 2.1 above). We report in detail the results of using the M2 for antelope mesowear scores. For all other tooth

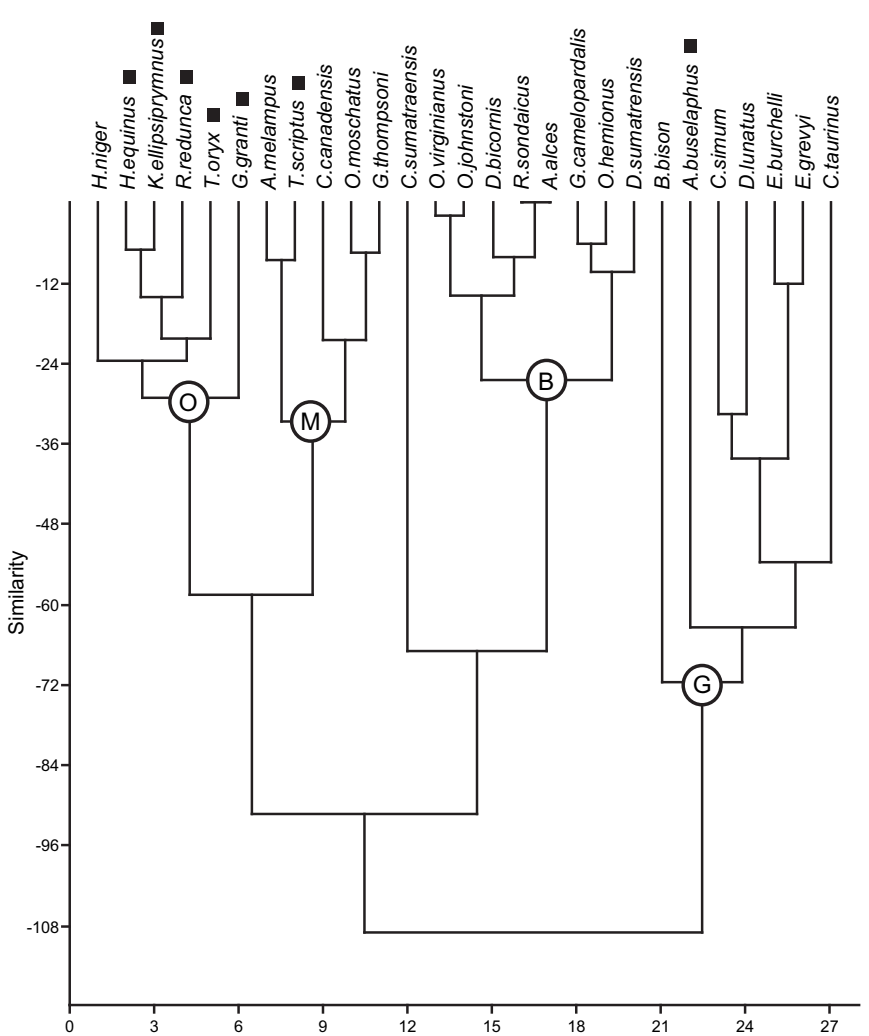

Fig. 2. Cluster analysis showing the topology of the 27 'typical' herbivore species with our antelope scores substituted for those of Fortelius and Solounias (2000). G = grazer $\mathrm{B}=$ browser, $\mathrm{M}=$ mixed feeder, $\mathrm{O}=$ other. Squares next to species indicate those 'typical' herbivores with our values substituted. 


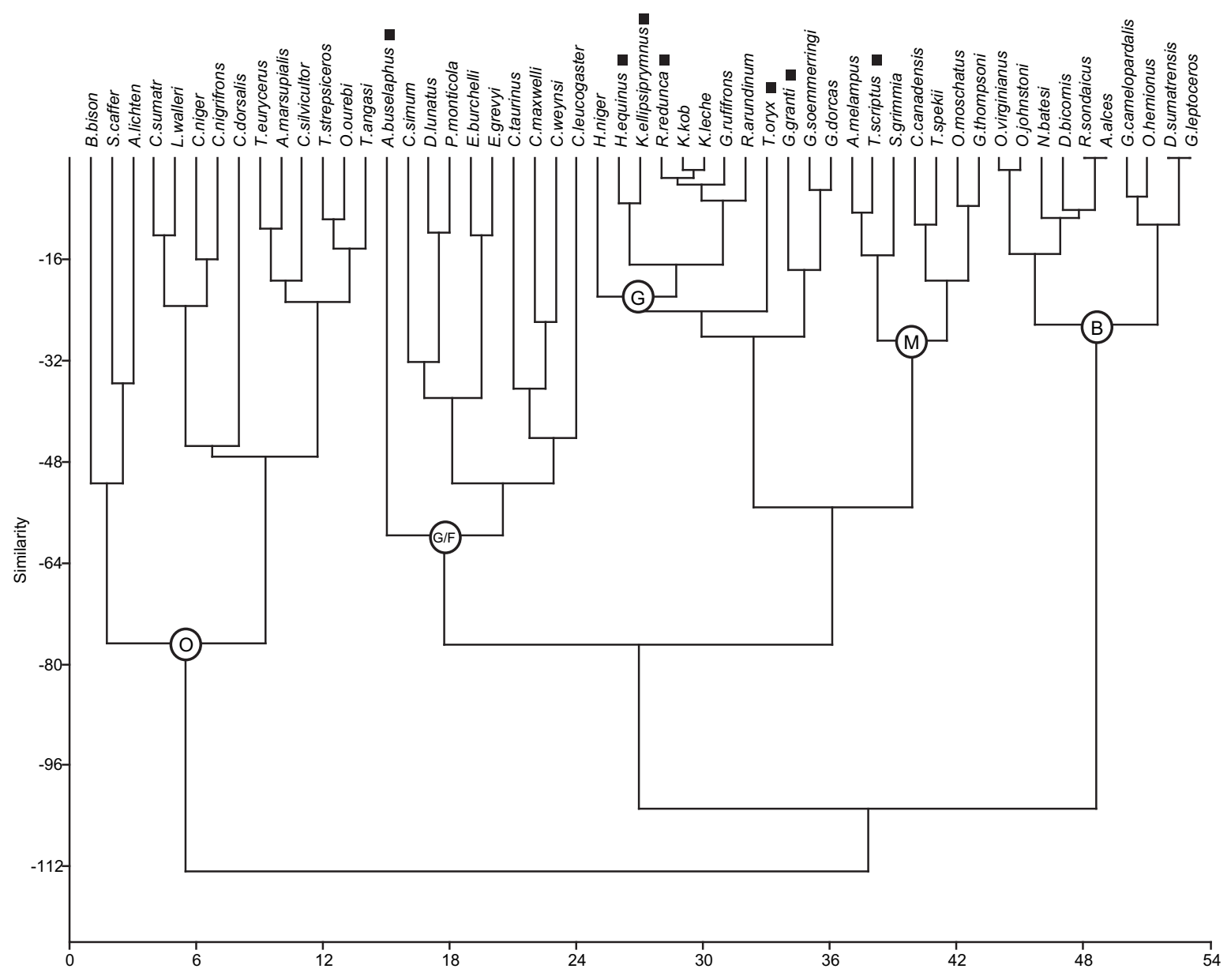

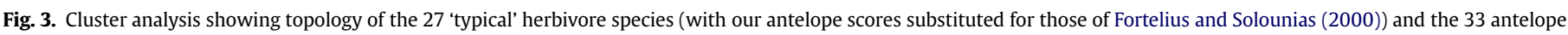

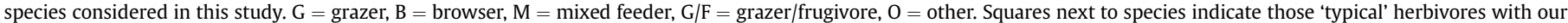
values substituted.

positions, we report only the jacknife results. That is, the number of species correctly classified into trophic category from a DFA constructed using all species except the classified one. This will most closely simulate the accuracy of any fossil classification.

\section{Results}

\subsection{Direct comparisons of mesowear values}

Mann-Whitney $U$ test of the mesowear values showed no significant differences for any mesowear variable across species measured for this study in common with Fortelius and Solounias
(2000): \%High $(p=0.07983)$; \%Sharp $(p=0.2673)$; \%Round $(p=0.07493)$; and \%Blunt $(p=0.07983)$.

\subsection{Comparisons between antelopes and 'typical' herbivores}

The first cluster analysis (Fig. 2) shows the 'typical' species of known diets, with our mesowear values replacing those of Fortelius and Solounias (2000). Distinct clusters representing the three dietary categories [grazer $(\mathrm{G})$, mixed $(\mathrm{M})$ and browser $(\mathrm{B})$ ] can be defined. Grazers form the most readily distinguishable cluster, though not exclusively as some grazers (Hippotragus niger, Hippotragus equinus and Kobus ellipsiprymmus) cluster with some mixed

Table 5

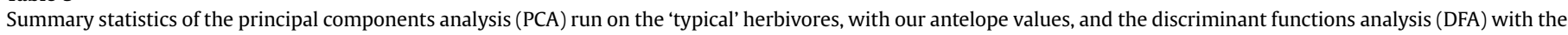

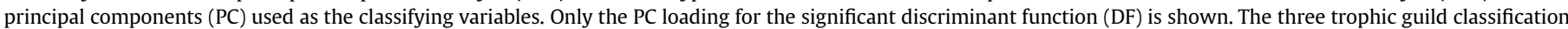
scheme was used as the classifying variables in the DFA.

\begin{tabular}{|c|c|c|c|c|c|c|c|}
\hline & Eigenvalue & \% variance & \%High & \%Sharp & \%Round & \%Blunt & Loading on DF1 \\
\hline PC1 & 2035.15000 & 64.95300 & -0.37210 & -0.68840 & 0.61860 & 0.07020 & 1.11616 \\
\hline PC2 & 981.59000 & 31.32800 & 0.85330 & -0.11940 & 0.41380 & -0.29370 & -0.24148 \\
\hline PC3 & 116.51100 & 3.71850 & -0.36510 & 0.42270 & 0.33680 & -0.75800 & -0.33777 \\
\hline \multirow[t]{2}{*}{ PC4 } & 0.00103 & 0.00003 & 0.00007 & 0.57720 & 0.57670 & 0.57810 & -0.48300 \\
\hline & Eigenvalue & $\% \mathrm{vc}$ & \multicolumn{2}{|c|}{ Wilk's Lambda } & Chi-square & df & Significance \\
\hline DF1 & 10.00500 & 96.1 & \multicolumn{2}{|c|}{0.06488} & 61.54380 & 8 & 0.00000 \\
\hline DF2 & 0.40100 & & \multicolumn{2}{|c|}{0.71395} & 7.58111 & 3 & 0.05551 \\
\hline
\end{tabular}



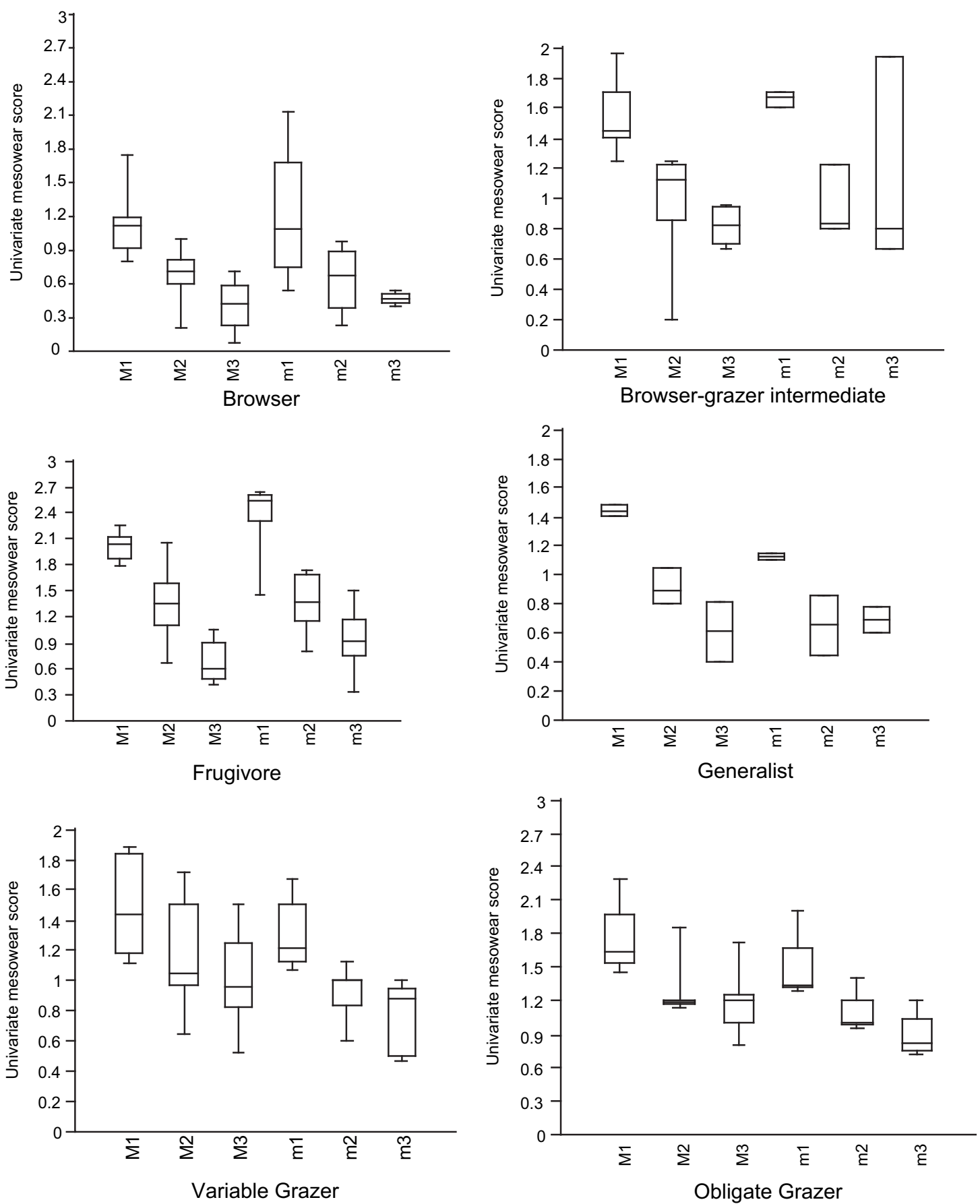

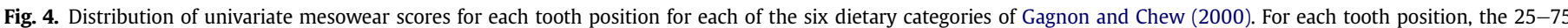

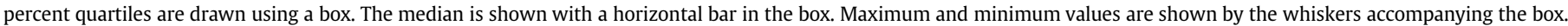

feeders (Redunca redunca and Taurotragus oryx) (group $\mathrm{O}$ in Fig. 2). The browser cluster is the only exclusive cluster; although in this analysis Capricornis sumatraensis, a typical Asian mixed feeder used by Fortelius and Solounias, clusters most closely with the browsers, we consider it to be separate from them.

The second cluster analysis (Fig. 3) again allows the discrimination of the three potential feeding categories (grazer, mixed and browser). We have interpreted the grazing cluster ( $G$ in Fig. 3 ) at the same approximate similarity level as the mixed feeders and browsers. Another, equally valid interpretation would consider this grazing cluster a subset within a larger mixed feeder cluster. Another cluster, which we have designated G/F, contains grazers and frugivores. The final cluster, designated $\mathrm{O}$ in Fig. 3, clusters grazers, browsers, frugivores and mixed feeders without any discernable pattern of trophic similarity.

Summary statistics for the DFA and PCA are shown in Table 5. The DFA resulted in two discriminant functions (DF), only the first of which was significant (Wilks' $\lambda=0.065, p<0.001$ ) and explained $96.1 \%$ of the variance. The highest loading on this function was PC1 (1.116). PC1 is, in turn, loaded positively by \%Round (0.6186) and negatively by \%Sharp $(-0.6884)$. Therefore, the first discriminant function is in large part being driven by the dichotomy between round and sharp cusps. It is however worth noting that \%High also loads PC1 in the same direction as \%Sharp $(-0.3721)$, albeit less 
than these two aforementioned variables. The DFA correctly classified $96.3 \%$ of original cases, the only exception being G. granti, which is classified as a grazer. In a jacknife analysis $92.6 \%$ of cases were correctly reclassified: $K$. ellipsiprymnus was incorrectly reclassified as mixed feeder, while $G$. granti was again reclassified as a grazer. Interestingly, G. granti is reported as a grazer by Lamprey (1963), and was also suggested to be a variable grazer (i.e. 60-90\% intake of monocots) by Gagnon and Chew (2000). Similarly, some studies report that for $K$. ellipsiprymnus, the proportion of grass ingested can be lower than 70\% during some seasons (Child and von Richter, 1969; Kiley, 1966).

Using this DFA, all but one of the antelope species not examined by Fortelius and Solounias (2000) was correctly classified. The only
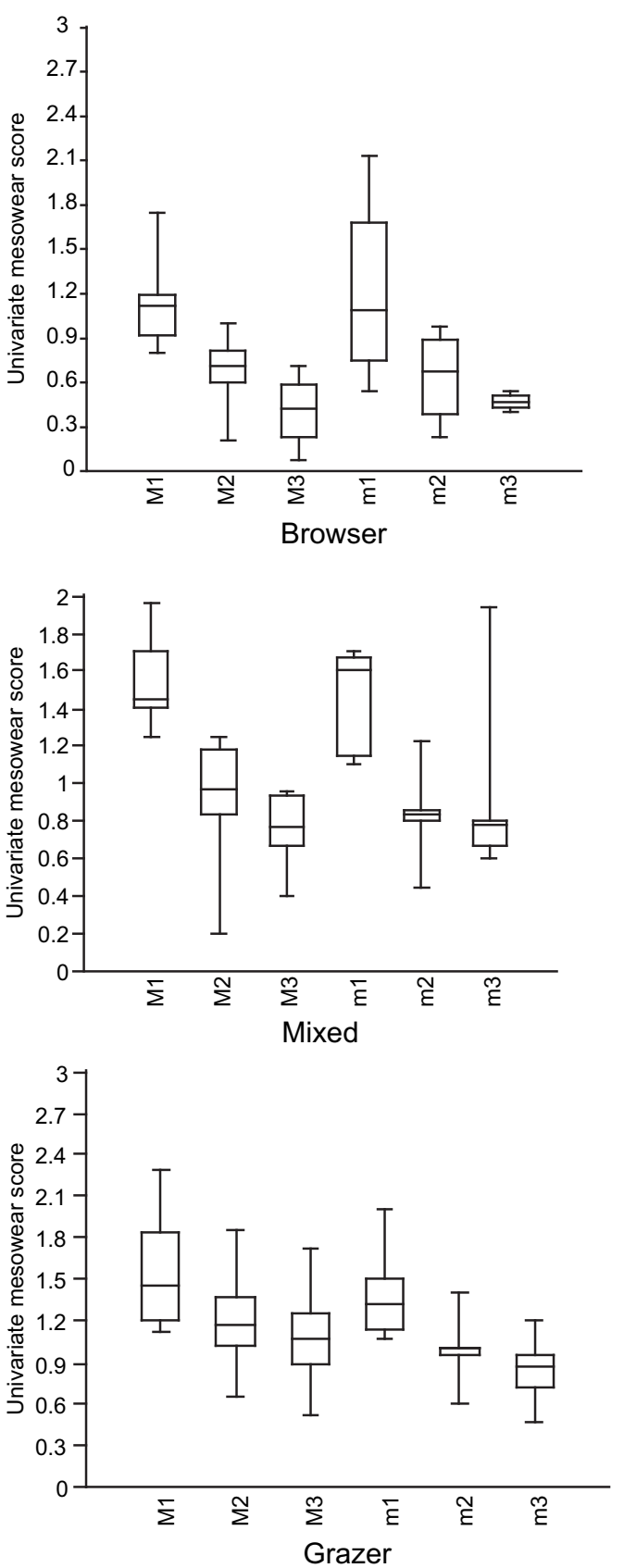

Fig. 5. Distribution of univariate mesowear scores for each tooth position for each of the reduced categories of browser, grazer and mixed feeder. For each tooth position, the 25-75 percent quartiles are drawn using a box. The median is shown with a horizontal bar in the box. Maximum and minimum values are shown by the whiskers accompanying the box. exception was Gazella soemmerringi, a grazer which was incorrectly classified as a mixed feeder.

\subsection{Intratrophic comparisons}

The distribution of mesowear scores across the different molars for the eight different trophic guilds is presented in Figs. 4 and 5 and the ANOVA results in Tables 6 and 7. The trend that emerges for all eight categories are differences in mesowear scores along the toothrow due to differences in eruption sequence. This pattern is the expected one. The first molar is the first to erupt, and is therefore in occlusion and used in mastication before any of the others. Therefore it is expected to experience a greater and earlier level of wear than molars which erupt subsequently. ANOVA results show that for most of the trophic categories, there is a significant difference between upper molars (Table 6). The only exceptions are the obligate grazers and variables grazers. However, significant differences between molars are found when these two categories are pooled into the 'grazer' category. Conversely, lower molars showed fewer statistical differences with regards to tooth position (Table 7). The only significant differences were observed in the frugivores and the grazers.

With regards to comparisons of the same tooth position but between upper and lower molars, we found that for the most part, mesowear scores were equivalent between them. The only three statistical differences we observed were between the first molars in frugivores ( $p=0.043238)$ and generalists $(p=0.017774)$, and the third molars of grazers $(p=0.045886)$. All other differences were not significant.

\subsection{Intertrophic comparisons}

The DFA was run on the M2 of antelope species within only the four diet categories (browser, grazer, mixed, frugivore). It returned three discriminant functions, only the first of which was significant (Table 8 ). Only $48.8 \%$ of antelope species were correctly reclassified in the jacknife analysis (Table 9). Only one browser, Litocranius walleri, was correctly reclassified; most other browsers were classified as mixed feeders. Most frugivores were correctly reclassified, the only exceptions being Cephalophus niger and Cephalophus nigrifrons, these being assigned to the browser guild. Only half of the grazers were correctly reclassified. The other half usually classified as either mixed feeders or browsers, the only exception being Alcelaphus lichtensteini which classified as a frugivore. Lastly, only half the mixed feeders correctly reclassified. The other half were assigned to the grazer guild, with the exception of Gazella leptoceros, which classified as a browser.

The cross-validated DFA results for each tooth position are shown in Table 10. Browsers achieved the highest level of correct reclassification with the $\mathrm{m} 3$ ( $75 \%$ of cases), mixed feeders with the M3 (66.7\% of cases), frugivores with the $m 1$ (87.5\% of cases) and grazers with the $\mathrm{m} 2$ (70\% of cases). Overall, the best performing tooth was the M3, which had an average correct reclassification rate of $55.2 \%$ across all four trophic categories, and with $56.7 \%$ of total species correctly reclassified. The first lower molar exhibited the lowest percentage of correctly reclassified cases with a rate of $35.6 \%$ across all four trophic categories, and with only $40.7 \%$ of total species correctly reclassified.

\section{Discussion}

\subsection{Comparisons between antelopes and 'typical' herbivores}

The cluster analysis of the 'typical' herbivores with our mesowear values for antelopes shows that the distribution of these 
Table 6

ANOVA and Tukey's post-hoc test results for differences between tooth position in average univariate mesowear scores for upper molars. Results for the six category trophic system (Gagnon and Chew, 2000), as well as the reduced four category trophic system used herein are presented.

\begin{tabular}{|c|c|c|c|c|c|}
\hline \multirow[t]{2}{*}{ Browser } & & & \multirow[b]{2}{*}{ MS } & \multirow[b]{2}{*}{ F-ratio } & \multirow[b]{2}{*}{$\mathrm{P}$} \\
\hline & SS & $\mathrm{df}$ & & & \\
\hline Between groups & 1.31283 & 2 & 0.656414 & 6.674 & 0.01265 \\
\hline Within groups & 1.08195 & 11 & 0.098359 & & \\
\hline \multicolumn{6}{|c|}{ Tukey's pairwise comparisons - $Q$ values; $P<0.05$} \\
\hline 0 & M1 & & $\mathrm{N}$ & & M3 \\
\hline M1 & - & & & & \\
\hline M2 & ns & & - & & \\
\hline M3 & 5.111 & & $\mathrm{n}$ & & - \\
\hline \multicolumn{6}{|l|}{ Browser-Grazer } \\
\hline & SS & df & MS & F-ratio & $\mathrm{P}$ \\
\hline Between groups & 1.46051 & 2 & 0.730257 & 7.083 & 0.01055 \\
\hline Within groups & 1.13417 & 11 & 0.103107 & & \\
\hline \multicolumn{6}{|c|}{ Tukey's pairwise comparisons - $Q$ values; $P<0.05$} \\
\hline 0 & M1 & & $\mathrm{N}$ & & M3 \\
\hline M1 & - & & & & \\
\hline M2 & 4.135 & & - & & \\
\hline M3 & 4.882 & & $\mathrm{n}$ & & - \\
\hline
\end{tabular}

Frugivore

\begin{tabular}{llllll}
\cline { 2 - 5 } & SS & df & MS & F-ratio & P \\
\hline Between groups & 7.07231 & 2 & 3.53616 & 38.71 & $<0.001$ \\
Within groups & 1.91835 & 21 & 0.09135 & &
\end{tabular}

Tukey's pairwise comparisons - $Q$ values; $P<0.05$

\begin{tabular}{|c|c|c|c|c|c|}
\hline 0 & M1 & & M2 & & M3 \\
\hline M1 & - & & & & \\
\hline M2 & 6.202 & & - & & \\
\hline M3 & 12.44 & & 6.241 & & - \\
\hline \multicolumn{6}{|l|}{ Generalist } \\
\hline & SS & df & MS & F-ratio & $\mathrm{P}$ \\
\hline Between groups & 0.707673 & 2 & 0.353836 & 11.67 & 0.0214 \\
\hline Within groups & 0.121274 & 4 & 0.030319 & & \\
\hline
\end{tabular}

Tukey's pairwise comparisons - $Q$ values; $P<0.05$

\begin{tabular}{|c|c|c|c|c|c|}
\hline 0 & M1 & & $\mathrm{M}$ & & M3 \\
\hline M1 & - & & & & \\
\hline M2 & ns & & - & & \\
\hline M3 & 7.141 & & ns & & - \\
\hline \multicolumn{6}{|l|}{ Obligate grazer } \\
\hline & SS & $\mathrm{df}$ & MS & F-ratio & $\mathrm{P}$ \\
\hline Between groups & 0.750206 & 2 & 0.375103 & 3.266 & 0.07702 \\
\hline Within groups & 1.26335 & 11 & 0.11485 & & \\
\hline \multicolumn{6}{|l|}{ Variable grazer } \\
\hline & SS & $\mathrm{df}$ & MS & F-ratio & $\mathrm{P}$ \\
\hline Between groups & 0.642626 & 2 & 0.321313 & 3 & 0.07507 \\
\hline Within groups & 1.92772 & 18 & 0.107096 & & \\
\hline \multicolumn{6}{|l|}{ Mixed } \\
\hline & SS & df & MS & F-ratio & $\mathrm{P}$ \\
\hline Between groups & 2.18716 & 2 & 1.09358 & 14.76 & $<0.001$ \\
\hline Within groups & 1.33351 & 18 & 0.074084 & & \\
\hline \multicolumn{6}{|c|}{ Tukey's pairwise comparisons - $Q$ values; $P<0.05$} \\
\hline 0 & M1 & & $\mathrm{M}$ & & M3 \\
\hline M1 & - & & & & \\
\hline M2 & 5.722 & & - & & \\
\hline M3 & 7.415 & & ns & & - \\
\hline
\end{tabular}

Table 6 (continued).

\begin{tabular}{llllll}
\hline Grazer & \multicolumn{5}{l}{} \\
\cline { 2 - 6 } & SS & df & MS & F-ratio & P \\
\hline Between groups & 1.28827 & 2 & 0.644135 & 5.746 & 0.007375 \\
Within groups & 3.58704 & 32 & 0.112095 & & \\
Tukey's pairwise comparisons - Q values; $P<0.05$ & & \\
\hline 0 & M1 & & M2 & M3 \\
\hline M1 & - & & & \\
M2 & ns & & - & & - \\
M3 & 4.706 & & ns & \\
\hline
\end{tabular}

variables within these species may not be altogether robust for this type of analysis. This contrasts with our DFA analysis, which had very high reclassification rates, both initial and jacknifed. While the majority of 'typical' species did cluster according to trophic guild, one cluster (labelled ' $\mathrm{O}$ ' in Fig. 2) contained a mix of grazers and mixed feeders. However we note that the grazers in this cluster, hippotragines and reduncines, are very different types of grazing animals than the alcelaphine, which was found in the grazing cluster (labelled ' $G$ ' in Fig. 2). Hippotragines live in bushland habitat, not open savanna, and reduncines are grazers of fresh grasses found near the water's edge. Both are considerably less hypsodont than alcelaphines, and their separation from other grazers may well be a result of this.

Within the cluster analysis of the 'typical' species and all antelope species (Fig. 3), we see some clustering along trophic guilds, though it does not seem particularly robust, with a significant cluster having no discernable trophic classification. Frugivores occupy their own cluster, but are most similar to some grazers. This may be due to the higher fibre content found in fruits compared to dicot leaves (Codron et al., 2007), causing a masticatory response in frugivores similar to some coarse grass grazers. However, frugivores should be readily distinguishable from grazers based on differences in hypsodonty and occusal pattern. Nevertheless, these findings strongly support the idea that frugivores should be analysed as a separate trophic guild from browsers.

The DFA run on the principal component scores of the 'typical' herbivores showed that most of the discrimination between grazer, browser and mixed feeder is a result of the dichotomy between the number of incidences of round cusps (positive loading) versus the incidences of sharp cusps and high relief (negative loading). \%Blunt was not selected, indicating that this variable plays a limited role in distinguishing diet.

\subsection{Intratrophic comparisons}

While within some trophic groups the differences between mesowear scores are not significantly different, we would still recommend that only teeth in the same position should be examined together and not substituted one for the other. The fact that the mesowear score is consistently observed across all molars and trophic categories suggests that all molars are amenable to mesowear analysis. The differences between mesowear scores across molars suggest that caution should be exercised when scoring a particular tooth, especially if the position of that tooth is unknown (e.g. for isolated teeth from archaeological assemblages).

Franz-Odendaal and Kaiser (2003) analysed upper and lower teeth of three ruminants (Ovibos moschatus, Ourebia ourebi, Giraffa camelopardis) and found differences between them that they attributed to differences in trophic guilds. They found that cusps of lower teeth tend to be less frequently sharp than upper teeth, and that upper and lower molars are more similar in specialised feeders 
Table 7

ANOVA and Tukey's post-hoc test results for differences between tooth position in average univariate mesowear scores for lower molars. Results for the six category trophic system (Gagnon and Chew, 2000), as well as the reduced four category trophic system used herein are presented.

\begin{tabular}{llllll}
\hline Browser & \multicolumn{5}{l}{} \\
\cline { 2 - 6 } & SS & df & MS & F-ratio & P \\
\hline Between groups & 1.21211 & 2 & 0.606056 & 3.228 & 0.08775 \\
Within groups & 1.68993 & 9 & 0.18777 & & \\
\hline Browser-Grazer & & & & & \\
\cline { 2 - 6 } & SS & df & MS & F-ratio & P \\
\hline Between groups & 0.801937 & 2 & 0.400969 & 2.234 & 0.1883 \\
Within groups & 1.07668 & 6 & 0.179446 & & \\
\hline
\end{tabular}

\begin{tabular}{llllll}
\hline Frugivore & \multicolumn{5}{l}{} \\
\cline { 2 - 6 } & SS & df & MS & F-ratio & P \\
\hline Between groups & 8.65589 & 2 & 4.32795 & 31.87 & $<0.001$ \\
Within groups & 2.85201 & 21 & 0.13581 & &
\end{tabular}

Tukey's pairwise comparisons - $Q$ values; $P<0.05$

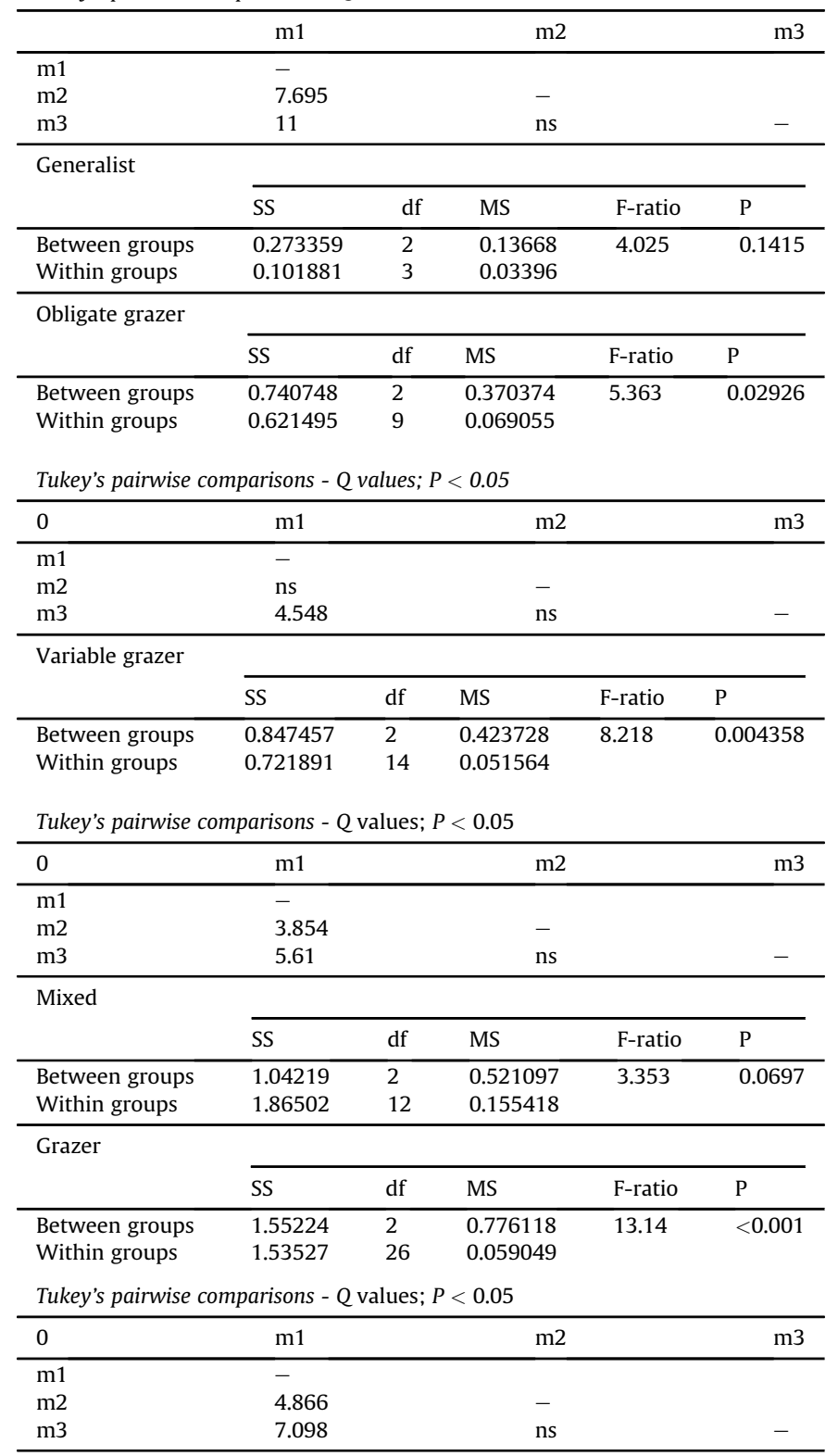

Table 8

Summary statistics for the discriminant functions analysis of the principal component scores of the mesowear variables for the upper M2 of the 33 antelope species examined in this study. The four trophic guild classification scheme was used as the classifying variables.

\begin{tabular}{llll}
\hline & DF1 & DF2 & DF3 \\
\hline Eigenvalue & 1.226 & 0.521 & 0.013 \\
\% variance & 69.6 & 29.6 & 0.8 \\
Wilk's Lambda & 0.291 & 0.649 & 0.987 \\
Chi-square & 34.521 & 12.114 & 0.373 \\
df & 12 & 6 & 2 \\
Significance & 0.001 & 0.059 & 0.830 \\
PC1 & 0.551 & -0.801 & 0.309 \\
PC2 & 0.825 & 0.541 & 0.112 \\
PC3 & 0.752 & -0.041 & -0.388 \\
PC4 & -0.059 & 0.304 & 0.805 \\
\hline
\end{tabular}

(namely grazers and browsers) compared to mixed feeders. Similarly, Kaiser and Fortelius (2003) found a shift towards the 'grazing edge' of mesowear values in lower teeth compared to upper teeth in horses. Unlike our study, these analyses used the percentage incidences of the different cusp and occlusal morphologies. Nevertheless, this result was not replicated in our analyses. We found very few differences between upper and lower molars with regards to the mesowear scores across all tooth positions and trophic categories.

\subsection{Intertrophic comparisons}

The intertrophic comparisons suggest that the first lower molars are the least suitable teeth for mesowear analysis. In this mode of analysis it may be that the extended period of wear for the first molar, relative to the later-erupting molars, is a disadvantage in discriminating differences between dietary categories, a result not altogether surprising. Overall the M3 is the best tooth

Table 9

Discriminant function classification of extant antelopes using the upper M2 of the 33 antelope species examined in this study. Diet category based on the reduced Gagnon and Chew (2000) classification described in the text. Correctly classified species are indicated in boldface.

\begin{tabular}{llll}
\hline Species & Diet & DF classification & Jacknife classification \\
\hline Alcelaphus buselaphus & Grazer & Grazer & Grazer \\
Alcelaphus lichtensteini & Grazer & Grazer & Frugivore \\
Antidorcas marsupialis & Mixed & Grazer & Grazer \\
Cephalophus dorsalis & Frugivore & Frugivore & Frugivore \\
Cephalophus leucogaster & Frugivore & Frugivore & Frugivore \\
Cephalophus maxwelli & Frugivore & Frugivore & Frugivore \\
Cephalophus niger & Frugivore & Browser & Browser \\
Cephalophus nigrifrons & Frugivore & Browser & Browser \\
Cephalophus silvicultor & Frugivore & Frugivore & Frugivore \\
Cephalophus weynsi & Frugivore & Frugivore & Frugivore \\
Gazella dorcas & Mixed & Mixed & Mixed \\
Gazella granti & Grazer & Grazer & Grazer \\
Gazella leptoceros & Mixed & Browser & Browser \\
Gazella ruffrons & Mixed & Grazer & Grazer \\
Gazella soemmerringi & Mixed & Mixed & Grazer \\
Hippotragus equinus & Grazer & Mixed & Mixed \\
Kobus ellipsiprymnus & Grazer & Mixed & Mixed \\
Kobus kob & Grazer & Grazer & Grazer \\
Kobus leche & Grazer & Grazer & Grazer \\
Litocranius walleri & Browser & Browser & Browser \\
Neotragus batesi & Browser & Browser & Frugivore \\
Ourebia ourebi & Grazer & Mixed & Mixed \\
Philantomba monticola & Frugivore & Frugivore & Frugivore \\
Redunca arundinum & Grazer & Grazer & Browser \\
Redunca redunca & Grazer & Grazer & Grazer \\
Sylvicapra grimmia & Browser & Mixed & Mixed \\
Syncerus caffer & Grazer & Grazer & Grazer \\
\hline & & &
\end{tabular}


Table 10

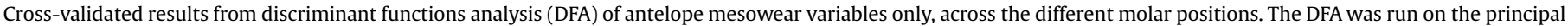

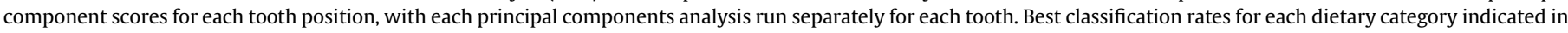

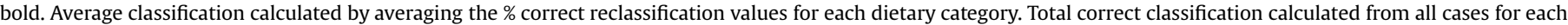
tooth position.

\begin{tabular}{|c|c|c|c|c|c|c|c|}
\hline & \multirow[t]{2}{*}{ Diet } & \multicolumn{4}{|c|}{ Predicted Group Membership } & \multirow[t]{2}{*}{$\%$ Average correct classification } & \multirow[t]{2}{*}{$\%$ Total correct classification } \\
\hline & & Browser & Mixed & Frugivore & Grazer & & \\
\hline \multirow[t]{4}{*}{ M1 } & Browser & 40.0 & 20.0 & 20.0 & 20.0 & 48.2 & 51.6 \\
\hline & Mixed & 14.3 & 14.3 & 28.6 & 42.9 & & \\
\hline & Frugivore & 12.5 & .0 & 75.0 & 12.5 & & \\
\hline & Grazer & 9.1 & 9.1 & 18.2 & 63.6 & & \\
\hline \multirow[t]{4}{*}{ M2 } & Browser & 20.0 & 60.0 & 20.0 & .0 & 48.8 & 51.5 \\
\hline & Mixed & 12.5 & 50.0 & .0 & 37.5 & & \\
\hline & Frugivore & 25.0 & .0 & 75.0 & .0 & & \\
\hline & Grazer & 16.7 & 25.0 & 8.3 & 50.0 & & \\
\hline \multirow[t]{4}{*}{ M3 } & Browser & 50.0 & 25.0 & 25.0 & .0 & 55.2 & 56.7 \\
\hline & Mixed & 16.7 & 66.7 & .0 & 16.7 & & \\
\hline & Frugivore & 12.5 & 37.5 & 37.5 & 12.5 & & \\
\hline & Grazer & .0 & 25.0 & 8.3 & 66.7 & & \\
\hline \multirow[t]{4}{*}{$\mathrm{m} 1$} & Browser & 25.0 & .0 & 25.0 & 50.0 & 35.6 & 40.7 \\
\hline & Mixed & 40.0 & .0 & .0 & 60.0 & & \\
\hline & Frugivore & .0 & 12.5 & 87.5 & .0 & & \\
\hline & Grazer & 10.0 & 50.0 & 10.0 & 30.0 & & \\
\hline \multirow[t]{4}{*}{$\mathrm{m} 2$} & Browser & 50.0 & 50.0 & .0 & .0 & 45.6 & 51.9 \\
\hline & Mixed & 40.0 & .0 & .0 & 60.0 & & \\
\hline & Frugivore & 12.5 & 12.5 & 62.5 & 12.5 & & \\
\hline & Grazer & 20.0 & 10.0 & .0 & 70.0 & & \\
\hline \multirow[t]{4}{*}{$\mathrm{m} 3$} & Browser & 75.0 & 25.0 & .0 & .0 & 41.7 & 42.3 \\
\hline & Mixed & .0 & .0 & 20.0 & 80.0 & & \\
\hline & Frugivore & 25.0 & 37.5 & 25.0 & 12.5 & & \\
\hline & Grazer & 22.2 & 11.1 & .0 & 66.7 & & \\
\hline
\end{tabular}

position to use in discriminating between the four trophic categories outlined in this study. Although we only examined each tooth individually, this result is similar to the findings of FranzOdendaal and Kaiser (2003), who suggested that a two-tooth model, consisting of the M2 and M3, may lead to better reclassification of diet. Despite this, however, when using only antelopes even the M3 doesn't provide a strong reclassification score on the basis of qualitative mesowear variables. This was somewhat surprising, as antelopes display the full range of herbivorous diets. We suggest that mesowear analyses using traditional mesowear variables still requires the full set of 'typical' herbivores to attain correct classifications.

\section{Conclusions}

Mesowear studies have advantages over other methods of determining palaeodiet which were recognised by the pioneers of this method (Fortelius and Solounias, 2000). Mesowear analyses are not destructive, and the primary data are simple to collect; researchers can easily be trained to a high level of accuracy ensuring relatively low inter-and intra-observer error (Kaiser et al., 2000). Particularly for applications of this method to past ecosystems, ground-truthing can be provided by alternative methods, such as carbon stable isotope analyses, (though these have the disadvantage of being both destructive, albeit minimally, and expensive) and microwear analyses (e.g. Rivals et al., 2007a). In addition, both hypsodonty index and occlusal crown pattern have been shown to correlate well with diet (Janis, 1988; Fortelius et al., 2006). Teeth are such a ubiquitous aspect of the fossil record that all aspects of them should be fully exploited to inform palaeoecological reconstructions. However, our analyses on modern African antelopes have shown that whilst mesowear studies have significant promise, their accuracy by themselves is often poorer than would be desirable to ensure an acceptable level of confidence.
Our study demonstrates that tooth position can affect the mesowear scores, and that there is a change in mesowear signal along the toothrow related to the degree of tooth wear. Treating different tooth positions synonymously with the M2 will likely cloud any effective mesowear signal, and we advocate that tooth position should be taken into account in any palaeodietary reconstruction using mesowear.

The discriminating power of 'typical' herbivores is much higher than that of the antelopes by themselves. This is likely a result of the extreme range and archetypal mesowear signature present in the 'typical' herbivore subset as opposed to the African antelope subset, despite the latter exhibiting the full range of herbivore diets. However, some extant species of antelopes were still misclassified when using cluster analysis (with our antelope values), though in the analysis examining only the 27 'typical' herbivores this may be due to the different types of grass ingested by different grazers. Nevertheless, we would suggest that cluster analysis may not be the most robust tool to use in examining mesowear. This is not a criticism of the method outlined by Fortelius and Solounias (2000); as they make clear in their paper, their aim was to provide an initial guide to mesowear regime. We would however urge a more cautious approach to interpretation of mesowear analyses, more so than is currently being shown.

\section{Acknowledgements}

We thank the curatorial and scientific staff at The Natural History Museum (London, UK), the Musée d'Histoire Naturelle de Paris (Paris, France) and the Koninklijk Museum voor MiddenAfrika (Tervuren, Belgium) for access to their material and hospitality at their museums. We are grateful for the comments of three anonymous reviewers which helped improve this manuscript, and S. Montanari for assistance with the figures. Financial support for this project was obtained from the Leverhulme Trust (F/00 754/C) as well as Synthesys grants FR-TAF-5488 and BE-TAF-4886 to J.L. 


\section{References}

Blondel, C., Merceron, G., Andosaa, L., Taisso, M.H., Vignaud, P., Brunet, M., 2010 Dental mesowear analysis of the late miocene bovidae from toros-menalla (Chad) and early hominid habitats in central Africa. Palaeogeogr. Palaeoclimatol. Palaeoecol. 292, 184-191.

Child, G., von Richter, W., 1969. Observations on ecology and behavior of lechwe, puku, and waterbuck along the Chobe River, Botswana. Z. Saugetierk. 34, 275-295.

Codron, D., Lee-Thorp, J.A., Sponheimer, M., Codron, J., 2007. Nutritional content of savanna plant foods: implications for browser/grazer models of ungulate diversification. Eur. J. Wildl. Res. 53, 100-111.

Croft, D.A., Weinstein, D., 2008. The first application of the mesowear method to endemic South American ungulates (Notoungulata). Palaeogeogr. Palaeoclimatol. Palaeoecol. 269, 103-114.

Fortelius, M., Solounias, N., 2000. Functional characterisation of ungulate molars using the abrasion-attrition wear gradient: a new method for reconstructing paleodiets. Am. Mus. Novit. 3301, 1-36.

Fortelius, M., Eronen, JT., Liu, L., Pushkina, D., Tesakov, A., Vislobokova, I.A Zhang, Z., 2006. Late miocene and pliocene large land mammals and climatic changes in Eurasia. Palaeogeogr. Palaeoclimatol. Palaeoecol. 238, 219-227.

Franz-Odendaal, T.A., Kaiser, T.M., 2003. Differential mesowear in the maxillary and mandibular cheek dentition of some ruminants (Artiodactyla). Ann. Zool. Fenn. 40, 395-410.

Gagnon, M., Chew, A.E., 2000. Dietary preferences in extant African bovidae. J. Mammal. 81, 490-511.

Hillson, S., 2005. Teeth, second ed. Cambridge University Press, New York

Janis, C.M., 1988. An estimation of tooth volume and hypsodonty indices in ungulate mammals, and the correlation of these factors with dietary preference. Mem. Mus. Natn. Hist. Nat. 53 (série C), 367-387. Paris.

Joomun, S.C., Hooker, J.J., Collinson, M.E., 2008. Dental wear variation and implications for diet: an example from eocene perissodactyls (Mammalia). Palaeogeogr. Palaeoclimatol. Palaeoecol. 263, 92-106.

Kaiser, T.M., Fortelius, M., 2003. Differential mesowear in occluding upper and lower molars: opening mesowear analysis for lower molars and premolars in hyposodont horses. J. Morphol. 258, 63-83.

Kaiser, T.M., Solounias, N., 2003. Extending the tooth mesowear method to extinct and extant equids. Geodiversitas 25, 321-345.

Kaiser, T.M., Solounias, N., Fortelius, M., Bernor, R.L., Schrenk, F., 2000. Tooth mesowear analysis on Hippotherium primigenium from the Vallesian Dinotheriensande (Germany) - a blind test study. Carolinea 58, 103-114.

Kaiser, T.M., Bernor, R.L., Franzen, J., Scott, R.S., Solounias, N., 2003. New interpretations of the systematics and palaeoecology of the dorn-dürkheim hipparions (late miocene, Turolian age [MN11]), Rheinhessen, Germany. Senckenb. Lethaea. 83, 103-133.

Kappelman, J., Plummer, T.W., Bishop, L.C., Duncan, A., Appleton, S., 1997. Bovids as indicators of Plio-pleistocene paleoenvironments of East Africa. J. Hum. Evol. 32, 95-129.

Kiley, M., 1966. A preliminary investigation into the feeding habits of the waterbuck by faecal analysis. E. Afr. Wildl. J. 4, 153-157.

Kovarovic, K.M., Andrews, P., Aiello, L., 2002. The palaeoecology of the upper Ndolanya beds, Laetoli, Tanzania. J. Hum. Evol. 43, 395-418.

Lamprey, H.F., 1963. Ecological separation of the large mammal species in the Taramgire Game Reserve, Tanganyika. E. Afr. Wildl. J. 1, 63-92.

Mihlbachler, M.C., Solounias, N., 2006. Coevolution of tooth crown height and diet in oreodonts (Myerycoidodontidae, Artiodactyla) examined with phylogenetically independent contrasts. J. Mammal. Evol. 13, 11-36.

Plummer, T.W., Bishop, L.C., 1994. Hominid paleoecology at olduvai gorge, Tanzania as indicated by antelope remains. J. Hum. Evol. 29, 321-362.

Plummer, T.W., Bishop, L.C., Hertel, F., 2008. Habitat preference of extant African bovids based on astragalus morphology: operationalizing ecomorphology for palaeoenvironmental reconstruction. J. Archaeol. Sci. 35, 3016-3027.

Rivals, F., Athanassiou, A., 2008. Dietary adaptations in an ungulate community from the late Pliocene of Greece. Palaeogeogr. Palaeoclimatol. Palaeoecol. 265, 134-139.

Rivals, F., Solounias, N., Mihlbachler, M.C., 2007a. Evidence for geographical variation in the diets of late pleistocene and early Holocene Bison in North America, and differences from the diets of recent Bison. Quaternary. Res. 68, 338-346.

Rivals, F., Mihlbachler, M.C., Solounias, N., 2007b. Effect of ontogenetic-age distribution in fossil and modern samples on the interpretation of ungulate paleodiets using the mesowear method. J. Vertebr. Paleontol. 27, 763-767.

Rivals, F., Schulz, E., Kaiser, T.M., 2008. Climate-related diversity of the ungulate faunas from the middle Pleistocene succession (OIS 14-12) at the Caune de Arago (France). Paleobiology 34, 117-127.

Rivals, F., Schulz, E., Kaiser, T.M., 2009. Late and middle Pleistocene ungulates dietary diversity in Western Europe indicate variations of Neanderthal paleoenvironments through time and space. Quaternary. Sci. Rev. 28, 3388-3400.

Schulz, E., Kaiser, T.M., Stubbe, A., Stubbe, M., Samjaa, R., Batsajchan, N., Wussow, J., 2007. Comparative demography and dietary resource partitioning of two wild ranging Asiatic equid populations. Erforsch. Biol. Ress. Mongolei. 10, 77-90.

Stynder, D.D., 2009. The diets of ungulates from the hominid fossil-bearing site of elandsfontein, Western Cape, South Africa. Quaternary Res. 71, 62-70.

Stynder, D.D., 2011. Fossil bovid diets indicate a scarcity of grass in the Langebaanweg E Quarry (South Africa) late Miocene/early Pliocene environments. Paleobiol 37, 126-139. 